\title{
Isolation of Vibrio harveyi from Diseased Kuruma Prawns Penaeus japonicus
}

\author{
Ping-Chung Liu, ${ }^{2}$ Kuo-Kau Lee, ${ }^{1}$ Kah-Ching Yii, ${ }^{1}$ Guang-Hsiung Kou, ${ }^{2}$ Shiu-Nan Chen ${ }^{2}$ \\ ${ }^{1}$ Department of Aquaculture, National Taiwan Ocean University, 2, Pei-Ning Road, Keelung, Taiwan 202, ROC \\ ${ }^{2}$ Department of Zoology, National Taiwan University, Taipei, Taiwan 106, ROC
}

Received: 22 November 1995 / Accepted: 24 February 1996

\begin{abstract}
Outbreaks of high mortality among the cultured kuruma prawn Penaeus japonicus without overt gross signs occurred during August and December of 1994 in I-Lan, Taiwan. Eleven luminous bacterial strains were isolated from the hepatopancreas of moribund prawns from five different farms by use of tryptic soy agar (TSA, supplemented with $2 \% \mathrm{NaCl}$ ) and/or thiosulfate citrate bile salt sucrose (TCBS) agar. These strains, together with our two previously unpublished isolates, were characterized and identified to be Vibrio harveyi in comparison with two ATCC Type strains and one strain previously isolated from the tiger prawn, $P$. monodon.
\end{abstract}

Vibriosis is one of the major threats in fish and shellfish marine aquaculture [1,11]. Vibrio species are known to cause serious diseases in the tiger prawn $(P$. mondon) in Taiwan [5, 12, 20, 21, 24]. However, the aquaculture of the kuruma prawn (Penaeus japonicus) has also resulted in high killoff in Taiwan since the summer of 1992 [24]. The white spot syndrome (WSS) in the carapace, similar to the syndrome described by Takahashi et al. [23] in the kuruma prawns, was the major finding in recent outbreaks in our survey; Vibrio alginolyticus was thought to play a significant role in the die-off of this WSS syndrome [24]. However, outbreaks of high mortality among the cultured kuruma prawns without overt gross signs also occurred during August and December of 1994 in I-Lan, Taiwan.

Mass die offs of tiger prawn larvae or juveniles associated with luminescence have been observed in hatcheries or farms in Australia [15], India [7], Indonesia [22], Thailand [6], the Philippines [2, 10], and Taiwan $[5,20]$. In this report we demonstrate and characterize the first luminous isolates from various outbreaks of vibriosis without WSS in the carapace or

Correspondence to: $\mathrm{K} . \mathrm{K}$. Lee other gross signs in the cultured kuruma prawn during August and December of 1994 in I-Lan, Taiwan.

\section{Materials and Methods}

Thirteen strains of Vibrio were used in this study: (1) Strain 770527 was isolated from the hepatopancreas(HP) of $P$. monodon during an outbreak of vibriosis; (2) strain 820514 was isolated from HP of diseased P. monodon; (3) strains $\mathrm{A} 1$ and $\mathrm{A} 2 ; \mathrm{B} 1$ and $\mathrm{B} 2 ; \mathrm{C} 1$ and $\mathrm{C} 2$; D1, D2 and D3; E1 and E2 were isolated from HP of diseased $P$. japonicus from $\mathrm{A}, \mathrm{B}, \mathrm{C}, \mathrm{D}$, and $\mathrm{E}$ farms, respectively, in I-Lan. These strains were isolated by use of tryptic soy agar (TSA, Oxoid, supplemented with $2 \% \mathrm{NaCl}$ ) and thiosulfate citrate bile salt sucrose agar (TCBS, Oxoid). In addition, one strain (In1) recently isolated from HP of $P$. monodon during an outbreak of vibriosis in Indonesia was also used for taxonomic comparison.

All cultures were stored in PBS $+10 \%$ glycerol at $-70^{\circ} \mathrm{C}$. Each strain was identified by standard morphological, physiological, and biochemical plate and tube tests, and the API 20E system (Bio Merieux, France). The reactions were compared with the reference strains $V$. harveyi ATCC 14126 [4] and V. harveyi ATCC 25919 [3]. Sources of bacterial strains used in this study are shown in Table 1.

\section{Results and Discussion}

Luminous bacteria were isolated from hepatopancreas of the kuruma prawn in five different farms (A-E) by use of TSA and/or TCBS agar plates (Fig. 1). The 
Table 1. Sources of bacterial strains used in this study

\begin{tabular}{|c|c|c|c|c|c|}
\hline Strains & Isolated origin & Organs & Localities & Month/year sampling & Reference \\
\hline \multicolumn{6}{|l|}{ Vibrio harveyi } \\
\hline ATCC $14126^{a}$ & Talorchestia sp. & $\mathrm{UN}^{b}$ & Mass. USA & UN & {$[4]$} \\
\hline ATCC 25919 & Sea water & & UN & UN & [3] \\
\hline 770527 & Penaeus monodon & $\mathrm{HP}^{c}$ & Chia-I, Taiwan & May/1988 & {$[5]$} \\
\hline 820514 & P. monodon & HP & I-Lan, Taiwan & May/1993 & \\
\hline $\ln 1$ & P. monodon & HP & Lampung, Indonesia & May/1995 & \\
\hline $\mathrm{A} 1^{d}$ & Penaeus japonicus & HP & I-Lan, Taiwan & Aug/1994 & \\
\hline $\mathrm{A} 2$ & P. japonicus & HP & I-Lan, Taiwan & Aug/1994 & \\
\hline B1 & P. japonicus & HP & I-Lan, Taiwan & Aug/1994 & \\
\hline B2 & P. japonicus & HP & I-Lan, Taiwan & Aug/1994 & \\
\hline $\mathrm{C} 1$ & P. japonicus & HP & I-Lan, Taiwan & Sep/1994 & \\
\hline $\mathrm{C} 2$ & P. japonicus & HP & I-Lan, Taiwan & Sep/1994 & \\
\hline D1 & P. japonicus & $\mathrm{HP}$ & I-Lan, Taiwan & Sep/1994 & \\
\hline D2 & P. japonicus & HP & I-Lan, Taiwan & Sep/1994 & \\
\hline D3 & P. japonicus & HP & I-Lan, Taiwan & Sep/1994 & \\
\hline E1 & P. japonicus & HP & I-Lan, Taiwan & Dec/1994 & \\
\hline E2 & P. japonicus & HP & I-Lan, Taiwan & Dec/1994 & \\
\hline
\end{tabular}

${ }^{a}$ ATCC, American Type Culture Collection, Rockville, MD, USA.

${ }^{b} \mathrm{UN}$, unknown.

${ }^{c} \mathrm{HP}$, hepatopancreas.

${ }^{d} \mathrm{~A}-\mathrm{E}$, five different farms.

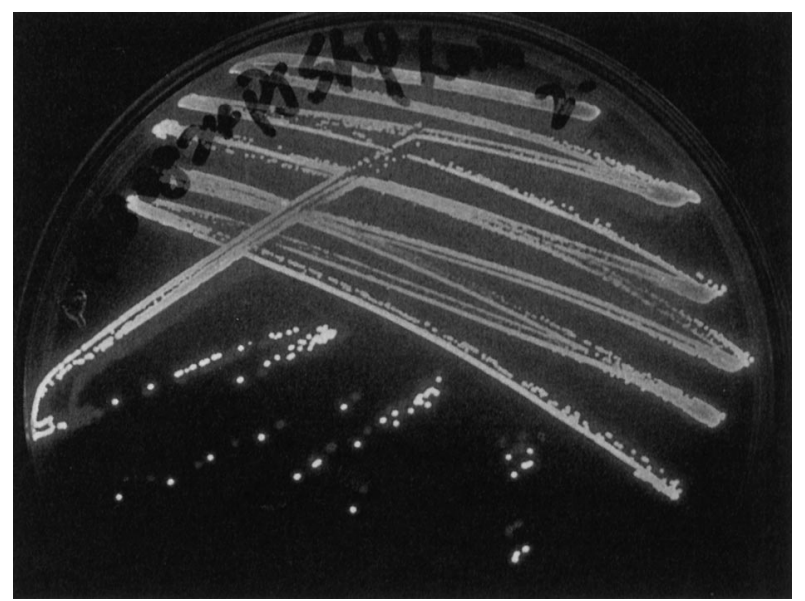

Fig. 1. Luminous colonies grown on tryptic soy agar (supplemented with $2 \% \mathrm{NaCl}$ ).

isolated bacteria were identified by standard morphological, physiological, and biochemical plate and tube tests and API 20E. Bacterial species identification was made following the scheme of Krieg and Holt [9]. The reactions were compared with two ATCC Type strains of $V$. harveyi originally isolated from sea water (ATCC 25919), luminescing amphipoda (ATCC 14126), and three strains $(770527,820514$, and In1) isolated from $P$. monodon. These bacterial isolates were Gramnegative, motile rods, oxidase- and catalase-positive, and produced green colonies on TCBS agar. In addition, these isolates failed to utilize inositol, sorbitol, and melibiose; they were all lysine decarboxylase-, ornithine decarboxylase-, and gelatinase-positive, and sensitive to the vibriostatic, 0/129. These isolates were identified as Vibrio harveyi. Table 2 shows the main biochemical characteristics of the isolated bacteria and reference strains. The present results suggest that perhaps more than one strain of $V$. harveyi caused the serious disease that occurred in cultured $P$. japonicus. More information is still needed concerning the groups of this species isolated from P. japonicus. (Group I and II of $V$. harveyi isolated from $P$. monodon were suggested by Pizzutto and Hirst [15] based on the protein profile of the bacterial cells).

Vibrio harveyi is ordinarily isolated from warm marine waters, surfaces of marine animals, light organs of certain marine fish and cephalopods, and intestines of aquatic animals [3, 13, 16-19], but only recently has the virulence of this species been recognized in a small but growing list of marine animals. These include the pearl oysters Pinctada maxima [14], the common snook Centropomus unidecimalis [8], and the penaeid prawns $[5,7,10,15,20]$. However, no record of vibriosis in kuruma prawns caused by $V$. harveyi has been reported. The transmission of the virulent strains between hosts, i.e., tiger prawn and kuruma prawn, could occur as $V$. harveyi was previously isolated from tiger prawns during outbreaks of vibriosis in 1993 in this region. Furthermore, $V$. harveyi was usually isolated from P. monodon during May and July in Taiwan (also see Table 1). However, 
Table 2. Comparison of biochemical characteristics of luminous bacterial strains isolated from diseased kuruma prawn, Penaeus japonicus in I-Lan, Taiwan with two Vibrio harveyi ATCC type strains and three strains previously isolated from tiger prawn, Penaeus monodon

\begin{tabular}{|c|c|c|c|c|c|c|c|c|c|c|c|c|c|c|c|c|}
\hline Test & ATCC 14126 & ATCC 25919 & $\begin{array}{c}770527 \\
(4)\end{array}$ & $\begin{array}{c}820514 \\
(4)\end{array}$ & $\begin{array}{l}\ln 1 \\
(3)\end{array}$ & $\begin{array}{l}\text { A1 } \\
\text { (5) }\end{array}$ & $\begin{array}{l}\text { A2 } \\
\text { (4) }\end{array}$ & $\begin{array}{l}\text { B1 } \\
(8)\end{array}$ & $\begin{array}{l}\text { B2 } \\
\text { (3) }\end{array}$ & $\begin{array}{l}\mathrm{C} 1 \\
(6)\end{array}$ & $\begin{array}{l}\mathrm{C} 2 \\
(1)\end{array}$ & $\begin{array}{l}\text { D1 } \\
\text { (3) }\end{array}$ & $\begin{array}{l}\text { D2 } \\
\text { (3) }\end{array}$ & $\begin{array}{l}\text { D3 } \\
\text { (1) }\end{array}$ & $\begin{array}{l}\text { E1 } \\
(12)\end{array}$ & $\begin{array}{l}\text { E2 } \\
\text { (2) }\end{array}$ \\
\hline \multicolumn{17}{|l|}{ Common characteristics } \\
\hline Gram stain & - & - & - & - & - & - & - & - & - & - & - & - & - & - & - & - \\
\hline Motility & + & + & + & + & + & + & + & + & + & + & + & + & + & + & + & + \\
\hline Swarming on $\mathrm{TSA}(+2 \% \mathrm{NaCl})$ & - & - & - & - & - & - & - & - & - & - & - & - & - & - & - & - \\
\hline \multicolumn{17}{|l|}{ Production of } \\
\hline $\mathrm{H} 2 \mathrm{~S}$ & - & - & - & - & - & - & - & - & - & - & - & - & - & - & - & - \\
\hline Indole & + & + & + & + & + & + & + & + & + & + & + & + & + & + & + & + \\
\hline Acetoin (V-P test) & - & - & - & - & - & - & - & - & - & - & - & - & - & - & - & - \\
\hline \multicolumn{17}{|l|}{ Presence of } \\
\hline$\beta$-galactosidase $\left(\mathrm{ONPG}^{a}\right.$ test $)$ & + & + & + & + & + & + & + & + & + & + & + & + & + & + & + & + \\
\hline Arginine dihydrolase & - & - & - & - & - & - & - & - & - & - & - & - & - & - & - & - \\
\hline Lysine decarboxylase & + & + & + & + & + & + & + & + & + & + & + & + & + & + & + & + \\
\hline Ornithine decarboxylase & + & + & + & + & + & + & + & + & + & + & + & + & + & + & + & + \\
\hline Tryptophane deaminase & - & - & - & - & - & - & - & - & - & - & - & - & - & - & - & - \\
\hline Gelatinase & + & + & + & + & + & + & + & + & + & + & + & + & + & + & + & + \\
\hline Cytochrome-oxidase & + & + & + & + & + & + & + & + & + & + & + & + & + & + & + & + \\
\hline Catalase & + & + & + & + & + & + & + & + & + & + & + & + & + & + & + & + \\
\hline \multicolumn{17}{|l|}{ Utilization of } \\
\hline Glucose & + & + & + & + & + & + & + & + & + & + & + & + & + & + & + & + \\
\hline Inositol & - & - & - & - & - & - & - & - & - & - & - & - & - & - & - & - \\
\hline Sorbitol & - & - & - & - & - & - & - & - & - & - & - & - & - & - & - & - \\
\hline Melibiose & - & - & - & - & - & - & - & - & - & - & - & - & - & - & - & - \\
\hline Nitrate reduction & + & + & + & + & + & + & + & + & + & + & + & + & + & + & + & + \\
\hline \multicolumn{17}{|l|}{ Inhibition by $0 / 129^{b}$ phosphate } \\
\hline $150 \mu \mathrm{g}$ & $\mathrm{S}$ & $\mathrm{S}$ & $\mathrm{S}$ & $\mathrm{S}$ & $\mathrm{S}$ & $\mathrm{S}$ & $\mathrm{S}$ & $\mathrm{S}$ & $\mathrm{S}$ & $\mathrm{S}$ & $\mathrm{S}$ & $\mathrm{S}$ & $\mathrm{S}$ & $\mathrm{S}$ & $\mathrm{S}$ & S \\
\hline Growth on $\mathrm{TCBS}^{c}$ & G & G & G & G & $\mathrm{G}$ & G & $\mathrm{G}$ & G & G & G & G & G & G & G & G & G \\
\hline \multicolumn{17}{|l|}{ Differential characteristics } \\
\hline Luminescence & + & - & - & + & + & + & + & + & + & + & + & + & + & + & + & + \\
\hline \multicolumn{17}{|l|}{ Presence of } \\
\hline Urease & - & - & - & + & + & + & - & + & - & + & - & - & - & + & + & - \\
\hline \multicolumn{17}{|l|}{ Utilization of } \\
\hline Citrate & - & + & - & - & - & - & - & - & + & - & + & + & - & - & - & - \\
\hline Mannitol & + & + & + & + & + & + & + & + & + & + & + & + & + & + & + & - \\
\hline Rhamnose & - & + & - & - & - & - & - & - & - & - & - & + & + & - & - & - \\
\hline Saccharose & - & - & - & - & - & - & - & - & - & - & - & - & - & + & - & - \\
\hline Amygdalin & + & + & + & + & + & + & + & + & + & + & + & + & + & - & + & + \\
\hline Arabinose & - & + & - & - & - & - & - & - & - & - & - & + & + & + & - & - \\
\hline
\end{tabular}

( ), number of isolates characterized; +, positive; -, negative; S, sensitive; G, colonies green.

${ }^{a}$ ONPG, o-nitrophenyl- $\beta$-D-galactopyranoside.

${ }^{b} 0 / 129$ phosphate, 2,4-diamino-6,7-diisopropyl-pteridine phosphate.

${ }^{c}$ TCBS, thiosulfate citrate bile salt sucrose agar.

our present results reveal that this species was isolated from the kuruma prawns during August and December. The reasons for the detection of this species in the kuruma prawns in a colder season and the high mortality are under investigation.

\section{ACKNOWLEDGMENTS}

This report was supported by grant COA-84-AST-2.16-FID03(02)-2 from the Council of Agriculture, ROC. We thank Mr. C.S. Wang for supplying the In1 strain used in this study.

\section{Literature Cited}

1. Austin B, Austin DA (1989) Methods for the microbiological examination of fish and shellfish. Chichester: Ellis Horwood Ltd

2. Baticados MCL, Lavilla-Pitogo CR, Cruz-Lacierda ER, de la Pena LD, Sunaz NA (1991) Studies on the chemical control of luminous bacteria $V$. harveyi and $V$. splendidus isolated from diseased P. monodon larvae and rearing water. Dis Aquat Org 9:133-139

3. Baumann P, Baumann L, Mandel M (1971) Taxonomy of marine bacteria: the genus Beneckea. J Bacteriol 107:268-294

4. Belas MR, Colwell RR (1982) Adsorption kinetics of laterally and polarly flagelatted Vibrio. J Bacteriol 115:1568-1580 
5. Chen SN, Huang SL, Kuo GH (1992) Studies on the epizootiology and pathogenicity of bacterial infections in cultured giant tiger prawns, Penaeus monodon, in Taiwan. In: Fulks W, Main KL (eds) Diseases of cultured penaeid shrimp in Asia and the United States. Hawaii: The Oceanic Institute, pp 195-205

6. Jiravanichpaisal P, Miyazaki T, Limsuwan C (1994) Histopathology, biochemistry, and pathogenicity of Vibrio harveyi infecting black tiger prawn Penaeus monodon. J Aquat Anim Health 6:27-35

7. Karunasagar I, Pai R, Malathi GR, Karunasagar I (1994) Mass mortality of Penaeus monodon larvae due to antibioticresistant Vibrio harveyi infection. Aquaculture 128:203-209

8. Kraxenberger-Beatty T, McGarey DJ, Grier HJ, Lim DV (1990) Vibrio harveyi, an opportunistic pathogen of the common snook, Centropomus unidecimalis (Bloch), held in captivity. J Fish Dis 13:557-560

9. Krieg NR, Holt JD (1984) Bergey's manual of systematic bacteriology, vol. 1. Baltimore/London: Williams and Wilkins

10. Lavilla-Pitogo CR, Baticados MCL, Cruz-Lacierda ER, de la Pena LD (1990) Occurrence of luminous bacterial disease of Penaeus monodon larvae in the Philippines. Aquaculture 91:1-13

11. Lightner DV (1988) Vibrio disease of penaeid shrimp. In: Sinderman CJ, Lightner DV (eds) Disease diagnosis and control in North American marine aquaculture and fisheries science, vol. 6. Amsterdam: Elsevier, pp 42-47

12. Liu CI (1990) The disease of cultured Penaeus monodon with emphasis on recent discoveries in Taiwan. In: Proceedings of ROC-Japan Symposium on Fish Diseases, 1989, Taipei, Taiwan, pp 180-201

13. O'Brien CH, Sizemore RK (1979) Distribution of the luminous bacterium Beneckea harveyi in a semitropical estuarine environment. Appl Environ Microbiol 38:928-933

14. Pass DA, Dybdahl R, Mannion MM (1987) Investigations into the causes of mortality of the pearl oyster, Pinctada maxima (Jamson), in Western Australia. Aquaculture 65:149-169

15. Pizzutto M, Hirst RG (1995) Classification of isolates of Vibrio harveyi virulent to Penaeus monodon larvae by protein profile analysis and M13 DNA fingerprinting. Dis Aquat Org 21: $61-68$

16. Ramesh A, Venugopalan VK (1987) Luminous microflora associated with the fishes Mugil cephalus and Tachysurus arius. FEMS Microbiol Ecol 53:27-34

17. Ramesh A, Venugopalan VK (1989) Response of enteric luminous bacteria to environmental conditions in the gut of the fish. J Appl Bacteriol 66:529-533

18. Ramesh A, Nandakumar R, Venugopalan VK (1986) Enteric luminous microflora of the pond-cultured milk fish Chanos chanos (Forskal). Microb Ecol 12:231-235

19. Ruby EG, Morin JG (1979) Luminous enteric bacteria of marine fish: a study of their distribution, densities and dispersion. Appl Environ Microbiol 38:406-411

20. Song YL, Lee SP (1993) Characterization of ecological implication of luminous Vibrio harveyi isolated from tiger shrimp (Penaeus monodon). Bull Inst Zool Acad Sin 32:217-220

21. Song YL, Cheng W, Wang CH (1993) Isolation and characterization of Vibrio damsela infectious for cultured shrimp in Taiwan. J Invertebr Pathol 61:24-31

22. Sunaryanto A, Mariam A (1986) Occurrence of a pathogenic bacteria causing luminescence in penaeid larvae in Indonesian hatcheries. Bull Brackishwater Aquacult Dev Cent 8:64-70

23. Takahashi Y, Itami T, Kondo M, Maeda M, Fujii R, Tomonaga S, Supamattaya K, Boonyaratpalin S (1994) Electron microscopic evidence of bacilliform virus infection in kuruma shrimp (Penaeus japonicus). Fish Pathol 29:121-125

24. Yu SR (1995) Studies on the characteristics of Vibrio alginolyticus and the lethal factor of the bacteria in Penaeus monodon and P. japonicus. Master's Thesis, National Taiwan Ocean University 